\title{
Oral and maxillofacial injuries in children: a retrospective study
}

\author{
Santanu Mukhopadhyay, Sauvik Galui, Raju Biswas, Subrata Saha, Subir Sarkar \\ Department of Pediatric and Preventive Dentistry, Dr. R. Ahmed Dental College and Hospital, Kolkata, India
}

\begin{abstract}
J Korean Assoc Oral Maxillofac Surg 2020;46:183-190)
Objectives: The purpose of this retrospective epidemiological study was to determine the etiology and pattern of maxillofacial injuries in a pediatric population.

Materials and Methods: Data for pediatric maxillofacial trauma patients aged 12 years and younger who were registered at the Department of Pediatric and Preventive Dentistry, Dr. R. Ahmed Dental College and Hospital, Kolkata, India, were reviewed and examined. Patients who were treated between October 2016 and September 2018 were analyzed according to age, sex, cause of injury, frequency and site of facial fractures, and soft tissue injuries. The chi-square tests were carried out for statistical analyses with a significance level of $5 \%$.

Results: Of 232 patients with a mean age of $6.77 \pm 3.25$ years, there were 134 males $(57.8 \%)$ and 98 females $(42.2 \%)$. The overall male to female ratio was 1.39:1. The most common causes of injuries were falls (56.5\%) and motor vehicle accidents (16.8\%). Incidence of falls decreased significantly with age $(P<0.001)$. Dentoalveolar injuries $(61.6 \%)$ and soft tissue injuries $(57.3 \%)$ were more common than facial fractures $(42.7 \%)$. Mandibular fractures $(82.8 \%)$ were the most common facial fractures, and perioral or lip injuries were the most prevalent injuries in our patient population. There was a positive association between facial fractures and soft tissue injury $(P<0.01)$ (odds ratio 0.26 ; confidence interval 0.15-0.46).

Conclusion: Falls were the leading cause of maxillofacial trauma in our sample of children, and the most common site of fractures was the mandible.
\end{abstract}

Key words: Maxillofacial injuries, Child, Epidemiology

[paper submitted 2019. 8. 31 / revised 2019. 12. 16 / accepted 2019. 12. 17]

\section{Introduction}

Facial fractures in the pediatric population are uncommon, accounting for $1.5 \%$ to $8.0 \%$ of injuries in children aged 12 years or younger, and less than $1 \%$ of injuries in children below the age of 5 years ${ }^{1}$. The low incidence of maxillofacial injuries in children has been attributed to the elasticity of facial bones, greater cranium to face ratio, thicker layer of adipose tissue, and lack of pneumatization of paranasal sinuses in young children. In addition, preschool children receive more parental care and are less independent than older children. However, the incidence of facial trauma increases as

\section{Sauvik Galui \\ Department of Pediatric and Preventive Dentistry, Dr. R. Ahmed Dental College and Hospital, 114 Acharya Jagadish Chandra Bose Road, Sealdah, Maula Ali, Crossing, Kolkata 700014, India \\ TEL: +91-33-22268509 FAX: +91-33-22268509 \\ E-mail: sauvikgalui92@gmail.com \\ ORCID: https://orcid.org/0000-0002-2415-0797}

(c) This is an open-access article distributed under the terms of the Creative Commons Attribution Non-Commercial License (http://creativecommons.org/ licenses/by-nc/4.0/), which permits unrestricted non-commercial use, distribution, and reproduction in any medium, provided the original work is properly cited. Copyright (C) 2020 The Korean Association of Oral and Maxillofacial Surgeons. All rights reserved. children age and become more exposed to outdoor activities.

According to the literature, motor vehicle accidents (MVA), falls from height, sports-related injuries, and interpersonal violence are the leading causes of maxillofacial injuries ${ }^{2-9}$. There is geographical variation in the incidence and pattern of maxillofacial trauma due to differences in socioeconomic, cultural, and environmental factors ${ }^{4-6}$. Epidemiological data regarding maxillofacial injuries are essential for clinical auditing, improving patient management, and the development of preventive strategies ${ }^{5,6}$. However, very few reports have investigated the epidemiology of facial trauma in the pediatric population, and none have focused on West Bengal, India. Therefore, the aim of the present study was to determine the etiological factors and patterns of maxillofacial injuries among children in this part of India.

\section{Materials and Methods}

\section{Study design and setting}

We performed a retrospective analysis of maxillofacial injuries in a pediatric population treated at the Department of 
Pediatric and Preventive Dentistry, Dr. R. Ahmed Dental College and Hospital, Kolkata, India, between October 2016 and September 2018. This institute, established in 1920 and affiliated with the West Bengal University of Health Sciences, is a tertiary care hospital and serves not only people living in the eastern part of India but also neighboring countries. The present study was performed in accordance with the declaration of Helsinki and received approval from the Institutional Review Board of Dr. R. Ahmed Dental College and Hospital (IRB No. DCH/73/8-19), and the written informed consent was obtained from all patients.

\section{Selection of patients and data collection}

Clinical records of all patients with maxillofacial injuries aged 12 years and younger were collected from the institution's injury report register for review. Over a period of two years, 257 patients were examined in our department. However, 35 patient files were excluded due to the nonavailability of radiographic findings, extensive head injury, and the presence of pathology. In addition, children reported to have only dentoalveolar trauma were excluded from this study. Finally, the clinical records of 232 pediatric subjects (134 males and 98 females) were investigated. These patients were divided into two groups according to age: 0-6 years and 7-12 years. Data collected from clinical records included age, sex, cause of injuries, type of injuries (soft tissue and hard tissue), and fracture sites. Associated injuries (head and limbs)

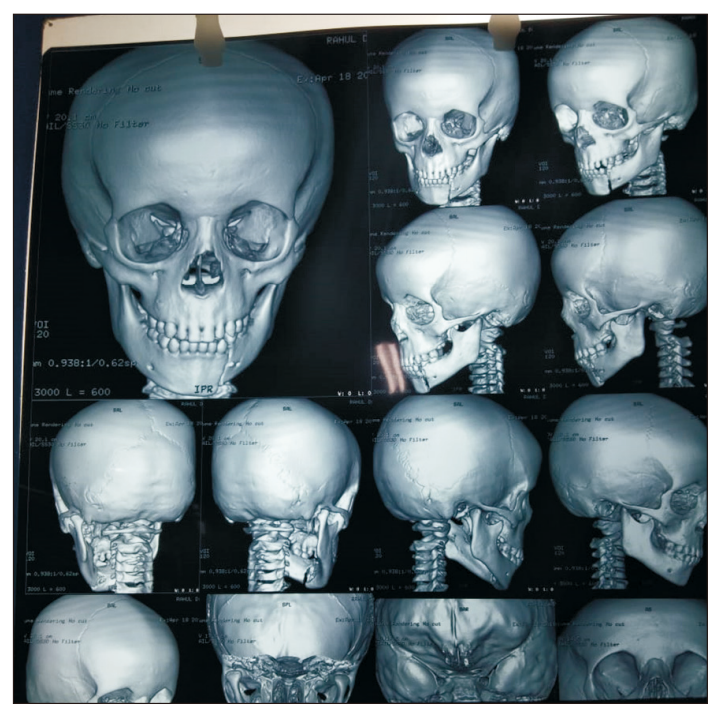

Fig. 1. Cone-beam computed tomography showing parasymphyseal fracture of the mandible.

Santanu Mukhopadhvav et al: Oral and maxillofacial injuries in children: a retrospective study. J Korean Assoc Oral Maxillofac Surg 2020 were also recorded. The etiology of trauma was classified as fall from height, MVA, play- or sports-related injury, bicycle accident, assaults or interpersonal violence, foreign body, trauma from a tube well handle, and animal-related injuries. Diagnoses of facial fractures were based on panoramic and/or computed tomographic examinations of the patients.(Fig. 1,2)

\section{Statistical analyses}

Statistical analyses were carried out using Epi Info (ver. 7.2; CDC, Atlanta, GA, USA). Descriptive statistics such as proportions, frequencies, and percentages were obtained. The chi-square tests were used for categorical variables, and for all analyses, a two-sided $P$-value was considered with significance level set at 5\% $(P<0.05)$.

\section{Results}

\section{Age and sex distribution}

Over a period of two years, a total of 232 records were examined for patients ranging in age between 0 and 12 years. The mean age of the patients was $6.77 \pm 3.25$ years. There were 134 males $(57.8 \%)$ and 98 females (42.2\%). Nearly half of the samples (114 patients, 49.1\%) were aged 0-6 years, and the other half (118 patients, 50.9\%) were aged 7-12 years. There was a male predominance in the sample and the overall male:female ratio was 1.39:1. The male:female ratio was higher in 7-12 year-old age group (1.6:1) compared with the $0-6$ year-old age group (1.1:1). However, the difference

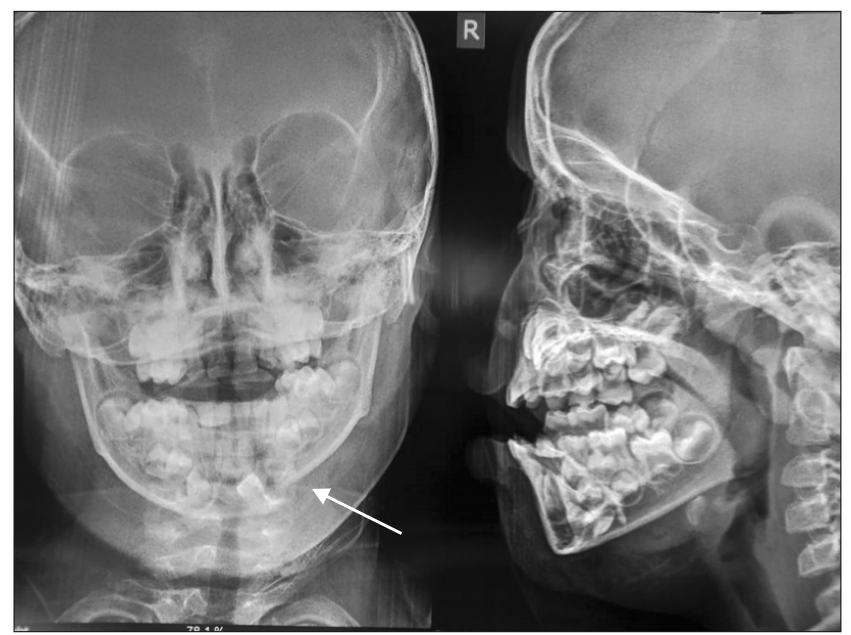

Fig. 2. Radiograph showing parasymphyseal fractures. Santanu Mukhopadhyay et al: Oral and maxillofacial injuries in children: a retrospective study. J Korean Assoc Oral Maxillofac Surg 2020 
between males and females was not statistically significant $(P=0.15)$. One hundred forty three patients $(61.6 \%)$ demonstrated dentoalveolar injuries. Facial bone fractures were observed in 99 patients $(42.7 \%)$ and 133 patients $(57.3 \%)$ sustained one or more soft tissue injuries.(Table 1)

\section{Etiology of maxillofacial injuries}

Table 2 shows the etiology of maxillofacial injuries in relation to age and sex. Fall from height was the most common cause of injury, accounting for $56.5 \%$ of cases. The frequency of falls varied significantly between the two age groups (71.9\% vs $41.5 \%, P<0.001)$. MVA $(16.8 \%)$ was the second most common cause in our patient population. Play- or sports-related injuries (12.1\%) ranked third and were significantly $(P=0.004)$ more frequent in children aged $7-12$ years. Bicycle accident $(6.0 \%)$, trauma from a tube well handle (3.9\%), animal-related injuries (2.6\%), assault (1.3\%), and foreign body $(0.9 \%)$ were the other causes of injury observed in this study.

\section{Pattern of maxillofacial injuries}

The distributions of facial fractures and soft tissue injuries are shown in Table 3.

A total of 112 facial bone fractures were observed in 99 patients. Mandibular fractures were the most frequent, accounting for $82.8 \%$ (82/99) of the cases.(Fig. 3) The incidence of mandibular fractures among males $(49 / 82,59.8 \%)$ was higher than among females $(33 / 82,40.2 \%)$.

In our sample, nasal bone fractures were seen in $22.2 \%$ $(22 / 99)$ of cases and males $(14 / 22,63.6 \%)$ outnumbered females (8/22, 36.4\%). Maxilla (4/99, 4.0\%), zygomatic, and orbital fractures ( 2 each, $2.0 \%$ ) were the next in order of frequency.(Fig. 3)

Of 143 children reported with dentoalveolar fractures, $58.7 \%(84 / 143)$ were males and $41.3 \%$ (59/143) were females. These injuries were slightly more common in children aged $7-12$ years $(48.3 \%, 69 / 143)$ compared with children aged $0-6$ years $(74 / 143,51.7 \%)$.(Fig. 4)

Among 133 patients who presented with soft tissue inju-

Table 1. Characteristics of the study population $(n=232)$

\begin{tabular}{|c|c|c|c|c|c|c|}
\hline \multicolumn{2}{|c|}{ Type of injury } & \multirow{2}{*}{$\frac{\text { Total }}{45(45.5)}$} & \multirow{2}{*}{$\frac{M(n)}{22}$} & \multirow{2}{*}{$\frac{F(n)}{23}$} & \multirow{2}{*}{$\begin{array}{l}\mathrm{M}: \mathrm{F} \\
1: 1.04\end{array}$} & \multirow{2}{*}{$\frac{P \text {-value }}{0.22}$} \\
\hline Facial fracture & $0-6 \mathrm{yr}$ & & & & & \\
\hline & $7-12 \mathrm{yr}$ & $54(54.5)$ & 34 & 20 & $1.7: 1$ & \\
\hline & Total & $99(100)$ & 56 & 43 & $1.3: 1$ & \\
\hline \multirow[t]{3}{*}{ Soft tissue injury } & $0-6 \mathrm{yr}$ & $67(50.4)$ & 35 & 32 & $1.9: 1$ & 0.53 \\
\hline & $7-12 \mathrm{yr}$ & $66(49.6)$ & 39 & 27 & $1.4: 1$ & \\
\hline & Total & $133(100)$ & 74 & 59 & $1.2: 1$ & \\
\hline \multirow[t]{3}{*}{ Dentoalveolar Injury } & $0-6 \mathrm{yr}$ & $69(48.3)$ & 36 & 33 & $1.09: 1$ & 0.17 \\
\hline & $7-12 \mathrm{yr}$ & $74(51.7)$ & 48 & 26 & $1.8: 1$ & \\
\hline & Total & $143(100)$ & 84 & 59 & $1.4: 1$ & \\
\hline
\end{tabular}

(M: male, F: female)

Values are presented as number $(\%)$ or number only.

$P$-values by chi-square test.

Santanu Mukhopadhyay et al: Oral and maxillofacial injuries in children: a retrospective study. J Korean Assoc Oral Maxillofac Surg 2020

Table 2. Etiology of maxillofacial injuries in relation to age and sex $(n=232)$

\begin{tabular}{|c|c|c|c|c|c|c|c|c|}
\hline \multirow{3}{*}{ Etiology } & \multicolumn{6}{|c|}{ Age group } & \multirow{3}{*}{$\begin{array}{c}\text { Total } \\
(\mathrm{n}=232)\end{array}$} & \multirow{3}{*}{$P$-value } \\
\hline & \multicolumn{3}{|c|}{$0-6 \mathrm{yr}$} & \multicolumn{3}{|c|}{$7-12 \mathrm{yr}$} & & \\
\hline & Total $(n=114)$ & $M(n=60)$ & $F(n=54)$ & Total $(n=118)$ & $M(n=74)$ & $F(n=44)$ & & \\
\hline Fall & $82(71.9)$ & 45 & 37 & $49(41.5)$ & 32 & 17 & $131(56.5)$ & $0.00001 *$ \\
\hline MVA & $17(14.9)$ & 7 & 10 & $22(18.6)$ & 12 & 10 & 39 (16.8) & 0.599 \\
\hline Play & $6(5.3)$ & 2 & 4 & $22(18.6)$ & 17 & 5 & $28(12.1)$ & $0.004 *$ \\
\hline Bicycle & $3(2.6)$ & 3 & 0 & $11(9.3)$ & 5 & 6 & $14(6.0)$ & 0.067 \\
\hline Tube well & $1(0.9)$ & 1 & 0 & $8(6.8)$ & 5 & 3 & $9(3.9)$ & $0.049 *$ \\
\hline Animal & $4(3.5)$ & 2 & 2 & $2(1.7)$ & 2 & 0 & $6(2.6)$ & 0.632 \\
\hline Assault & $0(0)$ & 0 & 0 & $3(2.5)$ & 0 & 3 & $3(1.3)$ & 0.26 \\
\hline Foreign body & $1(0.9)$ & 0 & 1 & $1(0.8)$ & 0 & 1 & $2(0.9)$ & 0.97 \\
\hline
\end{tabular}

(M: male, F: female, MVA: motor vehicle accident)

$* P<0.05$

Values are presented as number $(\%)$ or number only.

Santanu Mukhopadhyay et al: Oral and maxillofacial injuries in children: a retrospective study. J Korean Assoc Oral Maxillofac Surg 2020 
Table 3. Facial fractures and soft tissue injuries according to etiology

\begin{tabular}{|c|c|c|c|c|c|c|c|c|c|c|c|c|c|c|c|c|c|c|c|c|c|}
\hline \multirow{3}{*}{\multicolumn{2}{|c|}{ Etiology }} & \multicolumn{10}{|c|}{ Facial bone fracture } & \multicolumn{10}{|c|}{ Facial soft tissue injury } \\
\hline & & \multicolumn{2}{|c|}{ Mandible } & \multicolumn{2}{|c|}{ Nasal } & \multicolumn{2}{|c|}{ Maxilla } & \multicolumn{2}{|c|}{ Zygomatic } & \multicolumn{2}{|c|}{ Orbital } & \multicolumn{2}{|c|}{ Perioral } & \multicolumn{2}{|c|}{ Mental } & \multicolumn{2}{|c|}{ Intraoral } & \multicolumn{2}{|c|}{ Malar } & \multicolumn{2}{|c|}{ Frontal } \\
\hline & & M & $\mathrm{F}$ & M & $\mathrm{F}$ & M & F & M & F & M & $\mathrm{F}$ & M & $\mathrm{F}$ & M & F & M & F & M & $\mathrm{F}$ & M & $\mathrm{F}$ \\
\hline \multirow[t]{2}{*}{ Fall } & $0-6 \mathrm{yr}$ & 11 & 11 & 0 & 3 & 0 & 0 & 0 & 0 & 0 & 0 & 12 & 18 & 5 & 5 & 11 & 2 & 2 & 0 & 0 & 0 \\
\hline & $7-12 \mathrm{yr}$ & 10 & 5 & 1 & 1 & 1 & 0 & 0 & 0 & 0 & 0 & 5 & 4 & 6 & 4 & 3 & 1 & 1 & 2 & 1 & 1 \\
\hline \multirow[t]{2}{*}{ MVA } & $0-6 \mathrm{yr}$ & 5 & 7 & 2 & 0 & 1 & 0 & 0 & 1 & 0 & 1 & 1 & 3 & 1 & 1 & 0 & 2 & 2 & 2 & 1 & 1 \\
\hline & $7-12 \mathrm{yr}$ & 9 & 8 & 7 & 2 & 1 & 1 & 0 & 1 & 0 & 1 & 5 & 2 & 1 & 3 & 1 & 0 & 1 & 4 & 0 & 1 \\
\hline \multirow[t]{2}{*}{ Play } & $0-6 \mathrm{yr}$ & 1 & 1 & 0 & 0 & 0 & 0 & 0 & 0 & 0 & 0 & 0 & 0 & 0 & 0 & 0 & 0 & 0 & 0 & 0 & 0 \\
\hline & $7-12 \mathrm{yr}$ & 6 & 1 & 1 & 0 & 0 & 0 & 0 & 0 & 0 & 0 & 5 & 0 & 1 & 0 & 2 & 1 & 2 & 1 & 0 & 0 \\
\hline \multirow[t]{2}{*}{ Bicycle } & $0-6 \mathrm{yr}$ & 2 & 0 & 0 & 0 & 0 & 0 & 0 & 0 & 0 & 0 & 0 & 0 & 0 & 0 & 0 & 0 & 1 & 0 & 1 & 0 \\
\hline & $7-12 \mathrm{yr}$ & 1 & 1 & 0 & 2 & 0 & 0 & 0 & 0 & 0 & 0 & 2 & 2 & 0 & 1 & 0 & 0 & 0 & 1 & 0 & 1 \\
\hline \multirow[t]{2}{*}{ Tube well } & $0-6 \mathrm{yr}$ & 0 & 0 & 0 & 0 & 0 & 0 & 0 & 0 & 0 & 0 & 1 & 0 & 0 & 0 & 0 & 0 & 0 & 0 & 0 & 0 \\
\hline & $7-12 \mathrm{yr}$ & 1 & 0 & 0 & 0 & 0 & 0 & 0 & 0 & 0 & 0 & 2 & 0 & 1 & 2 & 1 & 0 & 0 & 0 & 0 & 0 \\
\hline \multirow[t]{2}{*}{ Animal } & $0-6 \mathrm{yr}$ & 0 & 0 & 2 & 0 & 0 & 0 & 0 & 0 & 0 & 0 & 1 & 1 & 0 & 0 & 0 & 1 & 0 & 1 & 1 & 0 \\
\hline & $7-12 \mathrm{yr}$ & 2 & 0 & 1 & 0 & 0 & 0 & 0 & 0 & 0 & 0 & 2 & 0 & 0 & 0 & 0 & 0 & 0 & 0 & 0 & 0 \\
\hline \multirow[t]{2}{*}{ Assault } & $0-6 \mathrm{yr}$ & 0 & 0 & 0 & 0 & 0 & 0 & 0 & 0 & 0 & 0 & 0 & 0 & 0 & 0 & 0 & 0 & 0 & 0 & 0 & 0 \\
\hline & $7-12 \mathrm{yr}$ & 0 & 0 & 0 & 0 & 0 & 0 & 0 & 0 & 0 & 0 & 0 & 3 & 0 & 1 & 0 & 0 & 0 & 0 & 0 & 0 \\
\hline \multirow[t]{2}{*}{ Foreign body } & $0-6 \mathrm{yr}$ & 0 & 0 & 0 & 0 & 0 & 0 & 0 & 0 & 0 & 0 & 0 & 0 & 0 & 0 & 0 & 1 & 0 & 0 & 0 & 0 \\
\hline & $7-12 \mathrm{yr}$ & 0 & 0 & 0 & 0 & 0 & 0 & 0 & 0 & 0 & 0 & 0 & 0 & 0 & 0 & 0 & 0 & 1 & 0 & 0 & 0 \\
\hline Total & & 49 & 33 & 14 & 8 & 3 & 1 & 0 & 2 & 0 & 2 & 36 & 33 & 15 & 17 & 18 & 8 & 10 & 11 & 4 & 4 \\
\hline
\end{tabular}

(M: male, F: female, MVA: motor vehicle accident)

Santanu Mukhopadhyay et al: Oral and maxillofacial injuries in children: a retrospective study. J Korean Assoc Oral Maxillofac Surg 2020

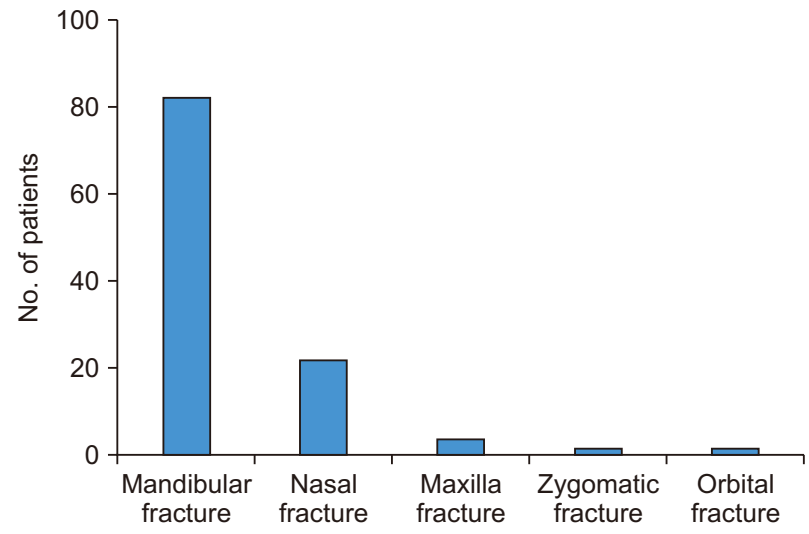

Fig. 3. Distribution of facial bone fracture types.

Santanu Mukhopadhyay et al: Oral and maxillofacial injuries in children: a retrospective study. J Korean Assoc Oral Maxillofac Surg 2020

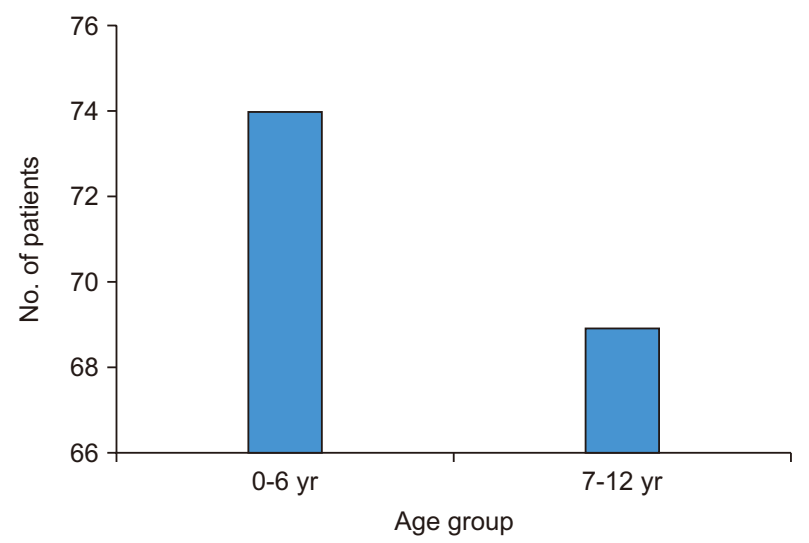

Fig. 4. Distribution of dentoalveolar fractures according to age. Santanu Mukhopadhyay et al: Oral and maxillofacial injuries in children: a retrospective study. J Korean Assoc Oral Maxillofac Surg 2020

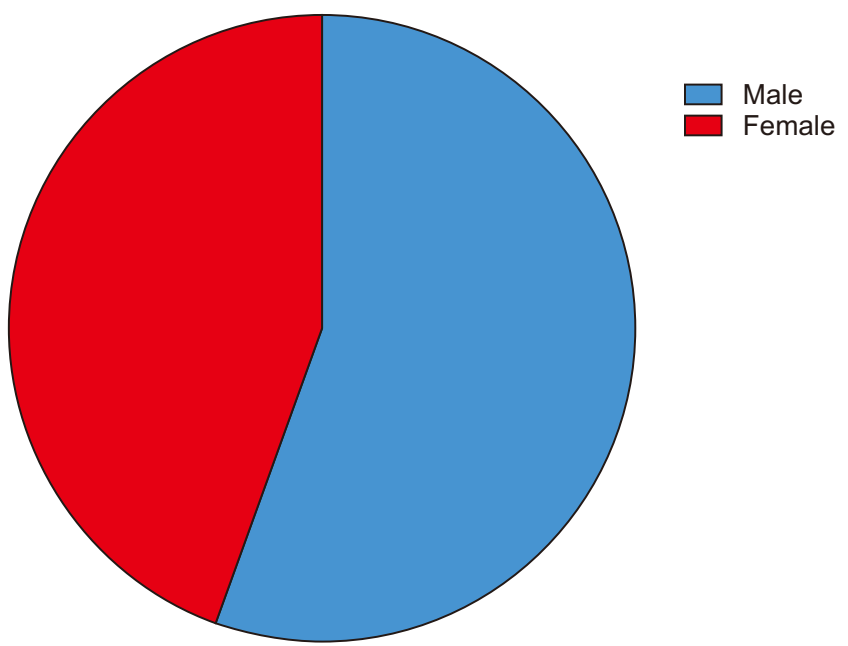

Fig. 5. Soft tissue injuries according to sex.

Santanu Mukhopadhyay et al: Oral and maxillofacial injuries in children: a retrospective study. J Korean Assoc Oral Maxillofac Surg 2020

ries, there were more males $(55.6 \%, 74 / 133)$ than females (44.4\%, 59/133).(Fig. 5)

Table 4 shows a positive association between facial fractures and soft tissue injury $(P<0.01)$ (odds ratio 0.26 ; confidence interval 0.15-0.46).

\section{Associated injuries}

Overall, 18 concomitant injuries were registered in 14 patients $(6.0 \%)$. These were as follows: head injuries $(27.8 \%$, $5 / 18)$, ophthalmic injuries, hand and leg $(22.2 \%, 4 / 18$ each), 
Table 4. Associations between facial fracture with sex, age, soft tissue injury and dentoalveolar injury

\begin{tabular}{|c|c|c|c|c|c|}
\hline & & \multicolumn{2}{|c|}{ Facial fracture } & \multirow{2}{*}{$\mathrm{OR}(\mathrm{CI})$} & \multirow{2}{*}{$P$-value } \\
\hline & & Yes & No & & \\
\hline \multirow[t]{2}{*}{ Sex } & Male & $56(56.6)$ & $78(58.6)$ & $0.91(0.54-1.55)$ & 0.85 \\
\hline & Female & $43(43.4)$ & $55(41.4)$ & & \\
\hline \multirow[t]{2}{*}{ Age group } & $0-6 \mathrm{yr}$ & $45(45.5)$ & $69(51.9)$ & $0.77(0.45-1.30)$ & 0.40 \\
\hline & $7-12 \mathrm{yr}$ & $54(54.5)$ & $64(48.1)$ & & \\
\hline \multirow[t]{2}{*}{ Soft tissue injury } & Yes & $39(39.4)$ & 94 (70.7) & $0.26(0.15-0.46)$ & $0.00000^{*}$ \\
\hline & No & $60(60.6)$ & $39(29.3)$ & & \\
\hline \multirow[t]{2}{*}{ Dentoalveolar injury } & Yes & $38(38.4)$ & 105 (78.9) & $0.16(0.09-0.29)$ & 0 \\
\hline & No & $61(61.6)$ & $28(21.1)$ & & \\
\hline
\end{tabular}

(OR: odds ratio, $\mathrm{CI}$ : confidence interval)

$* P<0.05$.

Values are presented as number (\%) or number only.

Santanu Mukhopadhyay et al: Oral and maxillofacial injuries in children: a retrospective study. J Korean Assoc Oral Maxillofac Surg 2020

and neck injuries $(5.6 \%, 1 / 18)$.

\section{Discussion}

Trauma is associated with significant morbidity and mortality in children. Although maxillofacial injuries are uncommon in children, when they occur they may lead to functional impairment and aesthetically unacceptable appearance. Several studies were carried out to understand the incidence and characteristics of pediatric maxillofacial injuries. In this study, we retrospectively evaluated maxillofacial injuries in a pediatric sample $(<12$ years).The mean age of the patients in this sample was $6.77 \pm 3.25$ years, which is comparable with the sample used in a previous study that reported a mean age of $6.5 \pm 3.72$ years among 0 - to 12 -year-old Pakistani children? ${ }^{7}$.

In this sample, boys suffered more facial injuries than girls, consistent with the findings of other reports. In fact, several previous investigations have suggested male predominance in the incidence of facial trauma, and the sex ratio in the literature varies between $1.6: 1$ and $3.3: 1^{8-11}$. In line with other reports, the male-to-female ratio in our sample increased progressively with age, from 1.1:1 in children aged 0-6 years to $1.6: 1$ in children aged 7-12 years ${ }^{12,13}$. According to CollaoGonzález et al. ${ }^{13}$, the less marked difference in preschool children might be due to age-related childhood activities. The greater male predominance in older children and adolescents could be due to the fact that males are more often involved in outdoor activities, sports, and violence. Karim et al. ${ }^{14}$ proposed that boys are more aggressive than girls, and therefore are more likely to get injured than girls.

Rowe ${ }^{15}$ reported that about $1 \%$ of all facial bone fractures occur before 6 years of age, while a total of $5 \%$ occur under the age of 12 years. Posnick et al. ${ }^{16}$ and Zimmermann et al. ${ }^{9}$ observed that the incidence of maxillofacial injuries increases as children begin school. Other research ${ }^{17-20}$ included major as well as minor orofacial injuries and observed a higher relative frequency of trauma in preschool children compared to school-age children. In our sample, trauma patients were almost equally divided among the preschool (0-6 years) and school-age (7-12 years) groups, probably due to the inclusion of minor soft tissue injuries and dentoalveolar fractures. We also observed that facial bone fractures were slightly more common (54.6\%) in children aged 7-12 years compared to children between 0-6 years of age, so much so that no significant difference $(P>0.05)$ was observed between these two age groups. This finding was not only in agreement with several previous Indian studies ${ }^{14,21}$, but also similar to some foreign studies $^{22,23}$. For example, the peak incidence of trauma occurred at the age of ten among 40 African children $(<11$ years) with maxillofacial injuries ${ }^{22}$. Alcalá-Galiano et al. ${ }^{24}$ and Rahman et al. ${ }^{25}$ also observed a greater incidence of maxillofacial injuries in children aged 6-12 years and older.

The incidence and pattern of facial fractures depend not only on socioeconomic status, culture, and geographical location, but also on the age of the sample studied. For example, Cavalcanti and $\mathrm{Melo}^{26}$ observed an incidence of facial fractures of $70 \%$ among 256 Brazilian patients with maxillofacial injuries aged 5-17 years. Osunde et $\mathrm{al}^{27}$ reported an incidence of $32 \%$ in children 15 years of age and younger in Nigeria. Kumaraswamy et al. ${ }^{11}$ observed facial fractures in 77 cases out of 95 patients (81\%) in an Indian pediatric sample less than 12 years of age. A recent Pakistani study also found a high incidence (88\%) of facial fractures in children aged 0-14 years ${ }^{28}$. We observed an overall incidence of facial fractures of $43 \%$ in the present study.

Fall from height was the predominant cause of facial trauma in our sample, accounting for $56.5 \%$ of cases. This find- 
ing is comparable with the results obtained by Kumaraswamy et al. ${ }^{11}$, Collao-González et al. ${ }^{13}$, Karim et al. ${ }^{14}$, and Cavalcanti and $\mathrm{Melo}^{26}$, who also reported falls as the leading cause of facial trauma. In contrast, Holland et al. ${ }^{23}$, Ul Haq and $\mathrm{Khan}^{28}$, Posnick et al. ${ }^{16}$, Osunde et al. ${ }^{27}$, and Kim et al. ${ }^{29}$ found that MVA was the most common cause of oral and maxillofacial trauma in their samples, possibly due to the inclusion of adolescents. In the present study, we observed that the incidence of falls decreased with age and varied significantly between children aged $0-6$ years and $7-12$ years $(71.9 \%$ vs $41.5 \%$, $P<0.001)$. On the other hand, MVA, bicycle accidents, sports related injuries, and trauma from tube well handles progressively increased with age. Young children tend to be prone to sustaining injuries through low velocity/energy traumas such as falls because their motor skills are not fully developed. However, when children begin school and are exposed to outdoor activities, the incidence of high energy/velocity trauma, such as MVA, bicycle accidents, sports-related injuries, and trauma from tube well handles increases. Additionally, the incidence of assault or interpersonal violence as a cause of injury was low in our sample (1.3\%). This incidence agrees with the results of a Nigerian study ${ }^{27}(3.8 \%)$ and an Austrian study $^{16}(3.9 \%)$, but is much lower than most reported in the literature ${ }^{6,8,29}$. Similarly, we observed a low frequency of animal-related facial injuries $(n=6,2.6 \%)$ and all but one were among rural residents. This is consistent with the findings of previous studies and supports the observation that human animal conflicts are more common in rural areas ${ }^{1,12}$.

In the present study, mandibular fractures were the most common facial fractures $(82.8 \%)$, and the frequency increased with age. This finding is in agreement with those of previous reports ${ }^{1,4,11,14,16}$. Although some studies have shown that nasal bone fractures are the most frequent facial fractures, they were only the second most common type of fracture $(22.2 \%)$ in our sample ${ }^{13,24,26}$. The lower incidence of mandibular fractures in preschool children compared to older children may be attributed to the retruded position of the face in relation to the skull in younger children. However, as age increases, the mandible grows inferiorly and anteriorly and the increased prominence of the middle and lower third of the face correspond to the greater incidence of mandibular and nasal fractures in older children and adolescents. Maxillary fractures constituted $4 \%$ all facial fractures in our sample, while zygomatic and orbital fractures were the least common $(2.0 \%)$, and most of those were due to MVA. This is consistent with the findings of other reports finding that midface fractures are uncommon in children and usually result from high-energy injuries such as MVA ${ }^{9,13,22}$.

The incidence of soft tissue injuries $(57.3 \%)$ in the present study was greater than the incidence of facial fractures (42.7\%), which agrees with the findings of other studies ${ }^{20,27}$. Furthermore, among the soft tissue injuries, perioral or lip injuries were the most prevalent in our sample. Yang et al. ${ }^{30}$ observed that soft tissue injuries are the most common in the lip region due to the prominence of the mandible. The incidence of dentoalveolar fractures was $61.6 \%$ in our sample, which agrees with the results found by Gassner et al. ${ }^{17}$ (76.3\%), but is greater than those found by Kumaraswamy et al. ${ }^{11}$ (42.1\%), Cavalcanti and $\mathrm{Melo}^{26}$ (25.8\%), and Osunde et al. ${ }^{27}$ (12.5\%). Zimmermann et al. ${ }^{9}$ reported that dentoalveolar fractures are very common in children and are often treated in the outpatient setting. Previous has also shown that type of trauma is generally related to the age of the population ${ }^{31}$.

Various studies have shown that $10 \%$ to $88 \%$ of patients with facial trauma present with associated injuries in other parts of the body $y^{4,9,23,24}$. Concomitant bodily injuries were registered in $6 \%$ of the patient population in our study. The wide variation in the frequency of associated injuries is largely attributed to variation in the mechanism of trauma.

The present study has limitations, which include small sample size and its retrospective nature. Furthermore, we did not study the outcomes of treatment, as treatment is carried out in the Department of Oral and Maxillofacial Surgery at our institution. In addition, our data were obtained from an injury report register maintained in the Department of Pediatric Dentistry, which included referred patients as well as patients coming directly to the outpatient department. Therefore, data from exclusive maxillofacial trauma centers may show different patterns.

\section{Conclusion}

In the present study, we found that male children are more susceptible to maxillofacial trauma than female children, although the male predominance was more pronounced in older children aged 7-12 years. Falls are the leading cause of injury in children, with the incidence of falls decreasing with age. Dentoalveolar and soft tissue injuries were more common than fractures of facial bones. Mandibular fractures were the most frequently occurring type of injuries. There was a positive association between facial bone fractures and soft tissue injuries. 


\section{ORCID}

Santanu Mukhopadhyay, https://orcid.org/0000-0002-7810-987X

Sauvik Galui, https://orcid.org/0000-0002-2415-0797

Raju Biswas, https://orcid.org/0000-0002-6467-1511

Subrata Saha, https://orcid.org/0000-0002-0146-6166

Subir Sarkar, https://orcid.org/0000-0002-9801-7198

\section{Authors' Contributions}

S.M. and S.G. contributed equally as first author, participated in data collection, conceptualization, study design and writing the manuscript. R.B. and S.S. (Subrata Saha) collected data, performed statistical analysis, helped to draft the manuscript. S.S. (Subir Sarkar) took part in revision and correction of manuscript. All authors read and approved the final manuscript.

\section{Ethics Approval and Consent to Participate}

The present study was performed in accordance with the declaration of Helsinki and received approval from the Institutional Review Board of Dr. R. Ahmed Dental College and Hospital (IRB No. DCH/73/8-19), and the written informed consent was obtained from all patients.

\section{Conflict of Interest}

No potential conflict of interest relevant to this article was reported.

\section{References}

1. Muñante-Cárdenas JL, Olate S, Asprino L, de Albergaria Barbosa JR, de Moraes M, Moreira RW. Pattern and treatment of facial trauma in pediatric and adolescent patients. J Craniofac Surg 2011;22:1251-5.

2. Mukhopadhyay S. A retrospective study of mandibular fractures in children. J Korean Assoc Oral Maxillofac Surg 2018;44:269-74.

3. Singaram M, G SV, Udhayakumar RK. Prevalence, pattern, etiology, and management of maxillofacial trauma in a developing country: a retrospective study. J Korean Assoc Oral Maxillofac Surg 2016;42:174-81.

4. Haug RH, Foss J. Maxillofacial injuries in the pediatric patient. Oral Surg Oral Med Oral Pathol Oral Radiol Endod 2000;90:12634.

5. Iida S, Matsuya T. Paediatric maxillofacial fractures: their aetiological characters and fracture patterns. J Craniomaxillofac Surg 2002;30:237-41.

6. Almahdi HM, Higzi MA. Maxillofacial fractures among Sudanese children at Khartoum Dental Teaching Hospital. BMC Res Notes
2016;9:120

7. Khan MA, Ishfaq M, Akhtar M, Rana SAA, Kashif M. Frequency of paediatric facial trauma in a tertiary care dental hospital. Int Surg J 2018;5:310-4.

8. Bregagnolo LA, Bregagnolo JC, Silveira Fd, Bérgamo AL, Santi LN, Watanabe MG. Oral and maxillofacial trauma in Brazilian children and adolescents. Braz Dent J 2013;24:397-401.

9. Zimmermann CE, Troulis MJ, Kaban LB. Pediatric facial fractures: recent advances in prevention, diagnosis and management. Int $\mathrm{J}$ Oral Maxillofac Surg 2006;35:2-13.

10. Leles JL, dos Santos EJ, Jorge FD, da Silva ET, Leles CR. Risk factors for maxillofacial injuries in a Brazilian emergency hospital sample. J Appl Oral Sci 2010;18:23-9.

11. Kumaraswamy SV, Madan N, Keerthi R, Singh DS. Pediatric injuries in maxillofacial trauma: a 5 year study. J Maxillofac Oral Surg 2009;8:150-3.

12. Khalifa GA, El-Kilani NS, Nasr TA. Clinical outcomes of pediatric maxillofacial fractures management in three hospital series in Egypt. J Oral Maxillofac Surg Med Pathol 2017;29:511-7.

13. Collao-González C, Carrasco-Labra A, Sung-Hsieh HH, CortésAraya J. Epidemiology of pediatric facial trauma in Chile: a retrospective study of 7,617 cases in 3 years. Med Oral Patol Oral Cir Bucal 2014;19:e99-105.

14. Karim T, Khan AH, Ahmed SS. Trauma of facial skeleton in children: an Indian perspective. Indian J Surg 2010;72:232-5.

15. Rowe NL. Fractures of the facial skeleton in children. J Oral Surg 1968;26:505-15.

16. Posnick JC, Wells M, Pron GE. Pediatric facial fractures: evolving patterns of treatment. J Oral Maxillofac Surg 1993;51:836-44; discussion 844-5.

17. Gassner R, Tuli T, Hächl O, Moreira R, Ulmer H. Craniomaxillofacial trauma in children: a review of 3,385 cases with 6,060 injuries in 10 years. J Oral Maxillofac Surg 2004;62:399-407.

18. Eggensperger Wymann NM, Hölzle A, Zachariou Z, Iizuka T. Pediatric craniofacial trauma. J Oral Maxillofac Surg 2008;66:58-64.

19. Chang LT, Tsai MC. Craniofacial injuries from slip, trip, and fall accidents of children. J Trauma 2007;63:70-4.

20. Kotecha S, Scannell J, Monaghan A, Williams RW. A four year retrospective study of 1,062 patients presenting with maxillofacial emergencies at a specialist paediatric hospital. Br J Oral Maxillofac Surg 2008;46:293-6.

21. Kambalimath HV, Agarwal SM, Kambalimath DH, Singh M, Jain N, Michael P. Maxillofacial injuries in children: a 10 year retrospective study. J Maxillofac Oral Surg 2013;12:140-4.

22. Oji C. Fractures of the facial skeleton in children: a survey of patients under the age of 11 years. J Craniomaxillofac Surg 1998;26:322-5.

23. Holland AJ, Broome C, Steinberg A, Cass DT. Facial fractures in children. Pediatr Emerg Care 2001;17:157-60.

24. Alcalá-Galiano A, Arribas-García IJ, Martín-Pérez MA, Romance A, Montalvo-Moreno JJ, Juncos JM. Pediatric facial fractures: children are not just small adults. Radiographics 2008;28:441-61; quiz 618.

25. Rahman RA, Ramli R, Rahman NA, Hussaini HM, Idrus SM, Hamid AL. Maxillofacial trauma of pediatric patients in Malaysia: a retrospective study from 1999 to 2001 in three hospitals. Int J Pediatr Otorhinolaryngol 2007;71:929-36.

26. Cavalcanti AL, Melo TR. Facial and oral injuries in Brazilian children aged 5-17 years: 5-year review. Eur Arch Paediatr Dent 2008;9:102-4

27. Osunde OD, Amole IO, Ver-or N, Akhiwu BI, Adebola RA, Iyogun $\mathrm{CA}$, et al. Pediatric maxillofacial injuries at a Nigerian teaching hospital: a three-year review. Niger J Clin Pract 2013;16:149-54.

28. Ul Haq ME, Khan AS. A retrospective study of causes, management, and complications of pediatric facial fractures. Eur J Dent 2018;12:247-52

29. Kim SH, Lee SH, Cho PD. Analysis of 809 facial bone frac- 
tures in a pediatric and adolescent population. Arch Plast Surg 2012;39:606-11.

30. Yang RT, Li Z, Li ZB. Maxillofacial injuries in infants and preschools: a 2.5-year study. J Craniofac Surg 2014;25:964-7.

31. Arenas M, Barbería E, Lucavechi T, Maroto M. Severe trauma in the primary dentition--diagnosis and treatment of sequelae in permanent dentition. Dent Traumatol 2006;22:226-30.
How to cite this article: Mukhopadhyay S, Galui S, Biswas R, Saha S, Sarkar S. Oral and maxillofacial injuries in children: a retrospective study. J Korean Assoc Oral Maxillofac Surg 2020;46:183-190. https://doi.org/10.5125/jkaoms.2020.46.3.183 